\title{
Economics for Agriculture
}




\title{
ECONOMICS FOR AGRICULTURE
}

\section{Food, Farming and the Rural Economy}

\author{
Berkeley Hill \\ and \\ Derek Ray
}




(C) Berkeley Hill and Derek Ray 1987

All rights reserved. No reproduction, copy or transmission of this publication may be made without written permission.

No paragraph of this publication may be reproduced, copied or transmitted save with written permission or in accordance with the provisions of the Copyright Act 1956 (as amended), or under the terms of any licence permitting limited copying issued by the Copyright Licensing Agency, 7 Ridgmount Street, London WC1E 7AE.

Any person who does any unauthorised act in relation to this publication may be liable to criminal prosecution and civil claims for damages.

First published 1987

Published by

MACMILLAN EDUCATION LTD

Houndmills, Basingstoke, Hampshire RG212XS

and London

Companies and representatives

throughout the world

British Library Cataloguing in Publication Data

Hill, Berkeley

Economics for agriculture: food, farming

and the rural economy.

1. Agriculture-Economic aspects-Great

Britain

I. Title II. Ray, Derek

338.1'0941 HD1925

ISBN 978-0-333-35225-0

ISBN 978-1-349-18782-9 (eBook)

DOI 10.1007/978-1-349-18782-9 
To Hilarie, Debbie, Tim and Emily Julia, Douglas, Duncan and Colin 


\section{Contents}

List of Figures xi

List of Tables xiii

Foreword xvi

Acknowledgements xviii

List of Abbreviations xix

1 Introduction and Overview 1

1 1.1 Changing Perspectives of Agriculture 1

1.2 Basic Trends and the State 4

1.3 The Integration of Agriculture 5

2 The Consumer End of the Food Chain 7

22.1 Introduction 7

2.2 Food Consumption in the UK 7

2.3 The Demand for Food 17

3 The Farmer and the Food Industry in the Food

3 Chain 42

3.1 The Importance of the Food Industry 42

3.2 Understanding the Food Chain 45

3.3 Stages in the Food Chain: (1) From the Farm Gate 50

3.4 Stages in the Food Chain: (2) Food Manufacturing 63

3.5 Stages in the Food Chain: (3) Food Distribution 68

3.6 Gross Marketing Margins 72

The Role of International Trade in the Food Chain 82

4.1 Introduction 82

4.2 Britain's International Trade in Agricultural Products 83

vii 
4.3 Agricultural Trade and the European Community 92

4.4 Trade and Self-sufficiency 100

\section{Agriculture in the National Framework 108}

5.1 A Broad Introduction to UK Agriculture 108

5.2 Agriculture in the European Community 119

5.3 The Changing Role of Agriculture in the Process of Economic Development 124

\section{Resources in Agriculture: Land 131}

6 6.1 The Quantity and Quality of Agricultural Land 131

6.2 The Ownership of Agricultural Land 137

6.3 The Use of Land for Farming - Land Tenure 141

6.4 The Use of Land for Farming - Cropping Pattern 149

6.5 Margins of Cultivation 151

6.6 The Market in Agricultural Land 155

6.7 Conclusions 164

Appendix: Major Legislation Affecting Agricultural Land 165

7 Resources in Agriculture: Labour 170

7.1 Numbers of People Engaged in Agriculture 170

7.2 Characteristics of Farmers 173

7.3 The Hired Labour Force 188

7.4 Motives and Goals 194

8 Resources in Agriculture: Capital and Finance 204

8.1 Investment and Stocks of Capital 204

8.2 Finance and Indebtedness 212

8.3 The Costs of Borrowing 220

( Farming Structure 223

9.1 The Meaning of the Term 'Structure' 223

9.2 Farm Businesses 226

9.3 The Size Structure of UK Farming Based on Areas of Holdings 229

9.4 Alternative Measures of Size 231

9.5 Types of Farm 238

9.6 Numbers and Sizes of Enterprises 240

9.7 An Explanation for Changing Farm and Enterprise Sizes 241

9.8 Farms as Businesses: The Fusion of Business and Family 245

9.9 Farms Run in Parallel with Other Businesses 249

9.10 Farm Size Structure and Policy 250 


\section{The Supply of Agricultural Products 253 \\ 10.1 Introduction 253 \\ 10.2 The Elementary Theory of Supply 256 \\ 10.3 Supply and the Price of the Commodity Itself 257 \\ 10.4 Supply and the Prices of Alternative Products 266 \\ 10.5 Supply and the Costs of Factors of Production 268 \\ 10.6 Supply and the Goals of Farmers 269}

\section{Change in the Supply of Agricultural Products: \\ 11 Technological Advance 271}

11.1 Technological Advance 271

11.2 Types of Innovation 272

11.3 Technological Change and Input Substitution 277

11.4 Industry, Regional and National Consequences of Technical Advance 277

11.5 The 'Treadmill' of Technological Advance 282

11.6 Rates of Diffusion of New Technology 284

11.7 A Model of the Process of Innovation by Farmers 288

11.8 The Future Direction of Technological Change 290

\section{Incomes and Agriculture 295}

12.1 The Agricultural Industry's Income 295

12.2 Incomes at the Farm Level 304

12.3 Farm Incomes in the UK 306

12.4 Instability of Farm Incomes 307

12.5 Absolute Levels of Farmer Incomes 310

12.6 Income, Wealth and Economic Status 314

12.7 Comparability of Rewards from Farming 316

12.8 A Retrospect on Farm Incomes 322

\section{The Price System and Agriculture 325}

13.1 Introduction 325

13.2 Price in a Free Market 325

13.3 Basic Demand and Supply Characteristics 327

13.4 Price Characteristics of Agriculture 328

13.5 Government Interference in the Market for Farm Products 335

13.6 Methods of Market Intervention 336

13.7 Manipulating Farm Prices 336

13.8 Intervention in the Market for Farming Inputs 350

13.9 Direct Payments to Farmers 354 


\section{Public Policy Towards Agriculture 359}

14.1 Policies and Agriculture 359

14.2 The Policy Process 361

14.3 Is There a UK or EC Agricultural Policy? 371

14.4 The Historical Development of Policy 372

14.5 The Stated Objectives of UK and EC Agricultural Policy 375

14.6 Policy As It Has Been Practised 377

14.7 Methods of Income Support 383

14.8 New Strands of Agricultural Policy 386

14.9 The National Interest 388

Appendix: A Historical Perspective on UK Agricultural Policy 390

\section{Agriculture in the Rural Economy 402}

15.2 Systems and Agricultural Policy 407

15.3 The Dangers of a Mono-disciplinary Approach 410

15.4 Agriculture and Other Sectors of the Rural Economy 411

15.5 Agriculture as an Employer and Income Generator 414

15.6 Agriculture as a Stimulator of Economic Activity 418

15.7 Other Ways of Stimulating the Rural Economy 422

15.8 Conclusion: Agriculture's Role in UK Rural

Development 423

Selected Further Reading 426

Index 435 


\section{List of Figures}

2.1 The Relationship between Consumption and Supply, Demand Curves

2.2 Demand at Retail and Farm Level

2.3 Potato and Fruit Consumption, 1983, by income group 30

3.1 The Food Chain in Britain

5.1 Agricultural Gross Output and Self-sufficiency (UK)

5.2 Dominant Systems of Farming in the United Kingdom

5.3 Relationships between Growth Rates in the Whole Economy and in the Agricultural Sector

6.1 Proportion of Holdings and Total Area in Rented and Mainly Rented Holdings, Great Britain

6.2 Distribution of Numbers of Holdings and Area by Tenure, England and Wales

6.3 The Cost of Farmland, 1790-1976

6.4 Land Values and Other Major Economic Indicators:

(a) nominal values; (b) Real Values

7.1 Age Distributions from the 1981 Population Census

9.1 Distribution of Numbers of Holdings and Total Area by Size of Holding, UK, 1982

10.1 A Typical Supply Curve

10.2 An Asymmetric Supply Curve

10.3 A Ratchet Supply Curve

10.4 A Reverse Supply Curve

11.1 The Effect of Technological Advance on the Supply Curve of an Agricultural Product

11.2 A Technical Advance with Higher Fixed Costs 275

11.3 Technical Advance and Input Substitution 278

11.4 The Treadmill of Technological Advance 283

11.5 Technological Advance Requiring Changed Input Prices For Its Uptake

11.6 The Adoption Process 
11.7 Fast and Slow Adopters of Technological Change

12.1 UK Farming Income and Other Economic Indicators, 1972-85

12.2 Output of Potatoes in Physical and Value Measures

12.3 Index of Real Income per Farm, England and Wales

12.4 Trends in net farm income in real terms, by type of farm, UK, $1977 / 8$ to $1985 / 6$

13.1 Year-to-year Variations in Price

13.2 The Progress of a Price Cycle

13.3 Input and Output Price Indices, EC (10)

13.4 The Changing Terms of Trade

13.5 A Buffer Stock

13.6 Support Buying

13.7 A Levy on Imports

13.8 Quota on Home Supply 344

13.9 Quota on Imports 346

13.10 Guaranteed Price and Deficiency Payment (No Foreign Supply)

13.11 Guaranteed Price and Deficiency Payment (With Imports) 348

13.12 A Bounty (Subsidy) on Production

13.13 A Tax on Production

13.14 A Subsidy on Inputs (No Imports) 353

13.15 A Subsidy on Inputs (with Imports of Product) 354

13.16 The Effect of an Input Subsidy on the Market for the Input

14.1 The Policy Process

14.2 Interaction Between Policies and Objectives

14.3 Public Institutions of Special Relevance to Agriculture in England and Wales

14.4 Directions From Which Policy Measures Impinge on Farming

15.1 Agriculture as a System within Systems

15.2 Percentage Distribution of Agricultural and Gross Domestic Product by Standard Statistical Region, and Agriculture's Share of Regional Product, 1983 


\section{List of Tables}

2.1 Expenditure on Household Food, 1983

2.2 Consumers' Expenditure on Food, 1983 and 1973-83 Percentage Change

2.3 Supplies Moving into Consumption, UK, kg. per person per year

2.4 Estimates of Price Elasticity of Demand for Selected Household Foods, 1978-83

2.5 Estimates of Price and Cross-price Elasticities of Demand, 1983

2.6 Inflation and Food Prices, 1961-84

2.7 Estimates of Income Elasticities of Demand for Selected Household Foods, 1983

2.8 Population Changes in Industrial Countries

3.1 Agriculture and the Food, Drink and Tobacco (FDT) Industries 1984

3.2 Price Structure for Milk, 1984-5, England and Wales 58

3.3 Food Manufacturing, $1984 \quad 65$

3.4 Food Retailers, 1982

3.5 Estimated Gross Marketing Margin, UK, 1974-84 73

3.6 Sales and Margins on Bacon, 1976

3.7 Margins on Poultry, $1974 \quad 76$

3.8 Gross Distribution Margin, Excluding Taxes: Fruit and Vegetables, Wholesale and Retail, 1978

4.1 Trade Indices for the UK, 1971-3 to 1984

4.2 Trade and Self-sufficiency in the UK for Selected Products 86

4.3 Industry $\times$ Industry Flow Matrix, UK, 1979

4.4 The Food Chain, $£$ billion, 1979 prices 93

4.5 EC Trade (External Only) in Food and Other Agricultural Products, million ECU, 1983

5.1 Agriculture's Share of Employment and Gross Domestic

Product - Selected Years

5.2 Composition of Total Output of UK agriculture 115 
5.3 Agricultural Activity in the Constituent Countries of the UK 118

5.4 The size of the agricultural sector in the EC

5.5 Agricultural employment and GNP per head - selected countries

6.1 An Estimate of Agricultural Land by Grades

6.2 Annual Transfers of Agricultural Land to Urban Use in England and Wales for Stated Periods

6.3 Ownership of Agricultural Land, GB, 1976

6.4 Land Use by UK Agriculture

6.5 Average Land Prices in England

7.1 Percentage of British Working Population Engaged in Agriculture: a Historical Perspective

7.2 Numbers of Persons Engaged in Agriculture, Selected Years, 1960-83

7.3 Family Composition of the Farm Labour Force, 1975

7.4 Distribution of Holdings by Age of Holder, 1983

7.5 Percentage Distribution of Whole-time Farmers, Partners and Directors by Age Group and Holding Area Size Group, England and Wales, December 1974

7.6 The Education of Farmers

7.7 Characteristics of Occupiers of Farms of 1000 Acres and Over Compared With an All-size Sample, East Anglia

7.8 Composition of Farming by Farm Size and Full- or Part-time Status, England, 1969

7.9 Percentage Distribution of Hired Regular Whole-time Men and Youths by Age Group, England and Wales, 1982

7.10 Average Earnings of Hired, Whole-time Adult Manual Male Workers

7.11 Values and Goals Associated with Farming

7.12 The Importance of Attributes of Farming to Cambridgeshire Farmers by Size of Farm Business

7.13 Factors Associated with Job Satisfaction by Farm Workers

8.1 Gross Fixed Capital Formation in UK Agriculture

8.2 Estimates of Capital Stocks (Central Statistical Office) UK, 1968-85

8.3 Agricultural Machinery in Use, UK, 1959-83

8.4 Estimated UK Farming Balance Sheet as at June 214

8.5 Loans to Agriculture 216

8.6 Advances by Banks and Specialised Land Mortgage Organisations

8.7 The Interest Burden on UK Farming 218

8.8 The Costs of Borrowing

9.1 Bases Frequently used for Describing the Structure of UK Agriculture 
9.2 Numbers of Holdings by Area Size Group 228

9.3 Farm Size Structure in the European Community, $1980 \quad 232$

9.4 Distribution of Holdings by SMD Size Group, 1976 and 1985

235

9.5 Farm Size in ESU and BSU: Class Average Physical Characteristics

9.6 Distribution of Farm Businesses by ESU Size Group UK 1982

9.7 Distribution of Holdings Between Types of Farming

9.8 Distribution of Dairy Cows Between Types of Farming

9.9 Size of Enterprises, UK, 1967-85

9.10 Business Forms in Farming, England, 1969

10.1 Estimated Average Yields of Crops and Livestock Products, UK

10.2 Supply Elasticity Estimates for the UK

11.1 Classification of Technological Advances, with Approximate Examples

12.1 The Output, Input and Income Account for UK Agriculture

12.2 UK Farming Income

12.3 Composition of Total Income of Couples and Individuals in the Trade Group Agriculture of the 1978/9 Survey of Personal Incomes

12.4 Changes in Income by Sector of UK Farming

12.5 Dispersal of Net Farm Incomes: Figures from the Farm Management Survey of England and Wales, 1976/7

12.6 Distribution of Incomes: All Incomes and Those in Agriculture and Horticulture

12.7 Ratio of Average Non-farm Earnings to Occupational

Earnings on Full-time Owner-occupied Farms - All Types (Excluding Horticulture)

13.1 Change in the Real Price of Agricultural Outputs and Inputs, 1970-82

13.2 Support arrangements for agricultural commodities 357

14.1 Stated Policy Aims of the UK MAFF, 1984

14.2 Membership of Some Key Farming and Environmental Organisations

15.1 Population Change in Different Categories of Local Government Districts in England and Wales, 1961-81

15.2 Percentage of Employed Residents Working in Various Industries, England and Wales, 1981

15.3 Manufacturing Employment Change in Urban and Rural Areas, 1960-78 


\section{Foreword}

This book emerged from a teaching course taken by a wide spectrum of second-year undergraduate students at Wye College. Mainly they were studying for degrees in agriculture and had already covered a course in basic economics. Mixed in with these were others following studies in environmental subjects and some specialist agricultural economists. From this original audience the nature of our text should be clear; it is aimed at any student at university or college level who requires a broad picture of the agricultural industry in the UK. In the 1980s it is no longer appropriate to assume that all students are young. There are many post-experience or part-time courses to cater for the wide spectrum of older people interested in rural issues. These also were in our minds and helped shape our approach. The language used is non-technical. Though a knowledge of economic principles is an advantage, a reader completely fresh to this area of study should find no difficulty in understanding our material.

In the past there has been a tendency to regard farming as separate from the consumer, understandable in view of the isolation from the free market that has typified this industry for the last half-century. In response to the increasing awareness that this isolationism is misguided and, for reasons described in this book, cannot continue, we have deliberately stressed the linkage of farming with the rest of the food chain. And as farming is only one user of rural resources, we attempt to look at its activities and use of the countryside within the context of the whole rural economy. Our focus is primarily on farming because this is the point from which most of our readers will start. However, by taking a broad view we hope that we have something to say not only to students involved with agriculture, narrowly defined, but to geographers, economists, natural scientists, sociologists, bankers, businessmen and people in other fields of interest on which agriculture impinges.

As a deliberate policy, when in this text changes are considered (and much of the reason for studying agriculture at all involves its changing nature) attention is given primarily to the medium and longer term. We 
concentrate on the more permanent trend characteristics that lie behind everyday issues of farming and the market for food in Britain. These trends help explain the problems faced by those actively engaged in farming and those who service the industry in a variety of ways.

In a text covering such a wide range of material it is inevitable that teachers will find that our degree of detail is not uniform. To some extent the balance here reflects our personal interests and estimations of what aspects of agriculture a reasonably well informed student should be aware. Nevertheless we hope that overall the text will be helpful and that we provoke the reader to explore the references.

Detectives of style may wish to know that Derek Ray is responsible for Chapters 2 to 4, Berkeley Hill for Chapters 5 to 9,11, 12,14 and 15. The remainder (Chapters 1, 10 and 13) have contributions from both.

BERKELEY HILL DEREK RAY 


\section{Acknowledgements}

The author and publishers wish to thank the following who have kindly given permission for the use of copyright material;

The Controller of Her Majesty's Stationery Office for tables and figures from the Annual Review of Agriculture (1986); Croom Helm Ltd for material from The Changing Countryside by B. Hill (1985); The Daily Telegraph for the graph 'The cost of farmland', August 1973; Department of Trade and Industry for material compiled by the Business Statistics Office, Business Monitor; European Review of Agricultural Economics for a figure from 'Inhibitors to change in agriculture: is a pluridisciplinary approach needed?' by S. L. Louwes, E.R.A.E. 4 (3); Faber \& Faber Ltd for figure from Agricultural Resources by A. Edwards and A. Rogers; Food and Agriculture Organization of the United Nations for table from FAO Agricultural Commodities Projections for 1970 (1962); Food for Britain for figure from 'Food Distribution: its Impact on Marketing in the 1980's' by J. J. Tanburn (1981); The Open University Press for table 'Characteristics of farmers in five categories ...' from D203 Decision Making in Britain: Agriculture, copyright (C) The Open University Press (1972); The Statistical Office of the European Community for material from EC publications Green Europe, National Accounts 1978 as Agricultural Situation in the European Community.

Every effort has been made to trace all the copyright-holders, but if any have been inadvertently overlooked the publishers will be pleased to make the necessary arrangement at the first opportunity. 


\section{Abbreviations and Glossary}

AAS

ACP

ADAS

Am. J. Ag. Econ.

ATB

BSU

Can. J. Ag. Econ.

CAP

CAS

CCAHC

CCD

CEAS

CGT

CLA

COMA

CSO

CTT

DAFS

DANI

DHSS

EAGGF
Annual Abstract of Statistics (London: HMSO)

African, Caribbean and Pacific countries (linked to the EC through the Lomé Agreement)

Agricultural Development and Advisory Service

American Journal of Agricultural Economics

Agricultural Training Board

British Size Unit

Canadian Journal of Agricultural Economics

Common Agricultural Policy of the EC

Centre for Agricultural Strategy, University of Reading

Central Council for Agricultural and Horticultural Cooperatives (incorporated into FFB, 1984)

Common Customs Duty (Also called Common

External Tariff. For all EC/non-EC trade. The

level of tariff varies from product to product)

Centre for European Agricultural Studies, Wye College, University of London

Capital Gains Tax

Country Landowners Association

Committee on the Medical Aspects of Food Policy (which reported to the DHSS)

Central Statistical Office

Capital Transfer Tax

Department of Agriculture and Fisheries for Scotland

Department of Agriculture for Northern Ireland

Department of Health and Social Security

European Agricultural Guidance and Guarantee Fund (also called FEOGA, its French acronym); 
EC

ECU (or ecu)

EDC

EEC

ESU

EUR (9)

Eur. Rev. Ag. Econ. FADN

FAS

FDI

FFB

FMS

GATT

GB

GDP

GNP

ha

HMSO

IDS

IGD

IR

JACNE

J. Ag. Econ.

LDC

LFA

LIC

MAFF that part of the European Fund of the EC allocated to CAP expenditure

European Communities (the official name for the European Economic Community, European Coal and Steel Community, and the European Atomic Energy Commission, which merged in 1967 to form the EC)

European Currency Unit

Economic Development Committee for Agriculture, part of the National Economic Development Office European Economic Community

European Size Unit

European Community with 9 member states; the addition of Greece raises the size to 10 , and Spain and Portugal to 12

European Review of Agricultural Economics

Farm Accountancy Data Network (also called RICA), based on national surveys of farm accounts in the EC

see FMS

Food and Drink Industries

Food From Britain

Farm Management Survey (in Scotland, the Farm Accounts Survey)

Part of the survey results are sent to the EC for FADN

General Agreement on Tariffs and Trade

Great Britain (England, Wales and Scotland)

Gross Domestic Product

Gross National Product

hectares

Her Majesty's Stationery Office

Institute of Development Studies

Institute for Grocery Distribution

Inland Revenue

Joint Advisory Committee on Nutrition Education (formerly NACNE), reporting to the DHSS

Journal of Agricultural Economics

Less Developed Country

Less Favoured Area (renamed Severely

Disadvantaged Area)

Lands Improvement Company

Ministry of Agriculture, Fisheries and Food 
MLC

MMB

NACNE

NEDO

NFS

NFU

OECD

PMB

SGM

Scot. J. Ag. Econ.

SGM

SLA

SMD

SPI

UAA

UHT

UK

USDA
Meat and Livestock Commission

Milk Marketing Board

see JACNE

National Economic Development Office

National Food Survey

National Farmers Union

Organisation for Economic Cooperation and

Development

Potato Marketing Board

Standard Gross Margin

Scottish Journal of Agricultural Economics

Standard Gross Margin

Scottish Landowners Association

Standard Man-days

Survey of Personal Incomes (by the IR)

Utilised Agricultural Area

Ultra Heat Treated

United Kingdom (England, Wales, Scotland and Northern Ireland)

United States Department of Agriculture 